\title{
Effect of Stocking Rate on Pasture Production, Milk Production, and Reproduction of Dairy Cows in Pasture-Based Systems
}

\author{
K. A. Macdonald, J. W. Penno, ${ }^{1}$ J. A. S. Lancaster, and J. R. Roche ${ }^{2}$ \\ DairyNZ (formerly Dexcel), Private Bag 3221, Hamilton, New Zealand
}

\begin{abstract}
Ninety-four cows were randomly allocated to 1 of 5 stocking rates $(2.2,2.7,3.1,3.7$, and 4.3 cows/ha) in a completely randomized design for 3 years. Herds were seasonal calving, with only minor differences in grazing management to optimize the profitability of each stocking rate $(\mathrm{SR})$. Pasture production and quality data, milk and milk component data, and reproduction data were collected, averaged for SR treatment, and linear and quadratic contrasts on SR were evaluated. In addition, the Wilmink exponential model $\left(\mathrm{y}_{\mathrm{t}}=\mathrm{a}+\mathrm{b} \times \mathrm{e}^{(-0.05 t)}+\right.$ $\mathrm{c} \times \mathrm{t}$ ) was fitted to milk yield within lactation, and the parameters were averaged by SR treatment and analyzed as above. The median variation explained by the function for individual lactations was $84 \%$. The amount of pasture grown tended to increase, and the quality of the pasture on offer increased linearly with increasing SR, reducing some of the negative impact of SR on the availability of pasture per cow. Milk production per cow declined linearly with increasing SR, although there was a tendency for most production variables to decline quadratically, with the negative effect of SR declining with increasing SR. The effect on milk production per cow was primarily because of a lower peak milk yield and a greater post-peak decline (less persistent milk profile), although a decline in lactation length with increasing SR was responsible for $24 \%$ of the effect of SR on milk yield. Milk production per hectare increased linearly with increasing SR, and there was only a small difference (approximately $3 \% /$ cow per ha) in the efficiency of converting feed dry matter into milk energy. Stocking rate did not affect reproductive success. The data are consistent with the need for a more robust measure of SR than cows per hectare because farms will differ in the genetic merit of their cows and in the potential to produce pasture. We introduce the concept of a comparative SR, whereby the carrying
\end{abstract}

Received August 22, 2007.

Accepted January 8, 2008.

${ }^{1}$ Current address: Synlait Ltd., RD 13, Rakaia, New Zealand.

${ }^{2}$ Corresponding author: john.roche@dairynz.co.nz capacity of the farm is defined by the BW of the cows, the potential of the land to produce pasture, and the amount of supplement purchased (kg of BW/t of feed dry matter). The adoption of such a measure would facilitate the extrapolation and transfer of research findings among systems.

Key words: milk production, pasture, stocking rate, comparative stocking rate

\section{INTRODUCTION}

There has been a rejuvenated interest in grazing production systems internationally, primarily as a result of long-term reductions in inflation-adjusted milk prices in many countries. Additionally, the proposed removal of subsidies (and therefore an even greater decline in milk price received at the farm gate), the use of milk quotas (Europe), rising labor, machinery, and housing costs, the cost of alternative feeds relative to grazed grass and milk, and perceived environmental and animal welfare concerns associated with intensive dairying (Dillon et al., 2005) have also contributed. In New Zealand, Australia, and many parts of western Europe, pasture can be the sole feed of the cow for long periods of lactation. This system is most suitable to temperate environments where pasture growth is seasonal, peaking in spring and declining to a minimum during the winter. The farming system most suited to this pasture growth pattern involves a compact calving period in spring just before the flush of spring pasture growth, attempting, to as great a degree as possible, to match the seasonal supply of pasture and the herd intake demand (Dillon et al., 1995).

The profitability of such dairy systems depends on the efficiency of pasture use coupled with reasonable per cow production (Dillon et al., 2005). Dry matter intake, the main determinant of milk production in such systems, is primarily controlled by pasture allowance (Maher et al., 2003). However, this relationship is curvilinear, with DMI increasing at a declining rate with increasing pasture allowance (Poppi et al., 1987). The curvilinear nature of this relationship points to a potential optimum pasture allowance for both biological and economic efficiency. Furthermore, pasture quality, 
another essential factor in milk production, tends to be positively associated with grazing severity in the previous defoliation (Lee et al., 2008), decreasing with higher grazing residuals (reduced grazing severity), and representing a potential reduction in future milk production with increasing pasture allowances. Therefore, although short-term studies may point to an optimum pasture allowance and hence stocking intensity for milk production in the short term, they provide little information on the optimum stocking density for the farm as a whole.

Stocking rate (SR) is defined as the number of animals allocated to an area of land (i.e., cows/ha), and it has been recognized as the primary driver of milk production per hectare and profitability in grazing systems for over half a century (McMeekan, 1956; Castle et al., 1972). Extension of short-term studies investigating the effect of pasture allowance on DMI and pasture utilization indicates an increase in pasture utilization and a decrease in per cow production as SR increases (Castle et al., 1968; Gordon, 1973; Baker and Leaver, 1986; Kennedy et al., 2006), and this is consistent with full lactation studies (Dillon et al., 1995). Increasing SR therefore negatively affects the amount of pasture available to each animal, but increases the amount of pasture harvested per hectare.

The potential to increase per hectare profitability by increasing $\mathrm{SR}$ when farms were under stocked has been reported (Fales et al., 1995). This is consistent with the positive association between milk production per hectare and SR in many studies (Gordon, 1973; Baker and Leaver, 1986; Dillon et al., 1995). However, many of these experiments were short term (Castle et al., 1968; Gordon, 1973; Baker and Leaver, 1986; Kennedy et al., 2006), compared insufficient SR treatments $(<3)$ to determine an optimum SR (Foot and Line, 1960; Castle et al., 1968; Gordon, 1973; Dillon et al., 1995), or included the use of purchased supplementary feeds (Fales et al., 1995), in effect modifying the true effect of SR on the biological (pasture utilization, milk production/cow, milk production/ha) and economic variables measured. Furthermore, much of this research is more than $30 \mathrm{yr}$ old and may no longer be applicable to the modern dairy cow breed and strains being used globally.

An additional problem with utilizing the information from previous studies is that the reported experiments involve cows differing in genetic merit for milk production and farm systems, in which pasture production per hectare and supplementary feed amounts can be greatly different. Both of these factors are likely to modify the effect of SR. Therefore, we propose that accounting for these confounding factors would result in a much more robust definition of SR than cows per hectare, as has been the definition in previous studies.
Of the 2 confounding variables mentioned, pasture grown per hectare each year can be reasonably accurately estimated by regular (e.g., weekly) visual assessments of each paddock on the farm. O'Donovan et al. (2002b) concluded that a linear regression of actual pasture yield (i.e., a cut sample) on a visual estimate of pasture yield explained $95 \%$ of the variation in the data, and the residual SD was $<12 \%$ of the pasture yield. In addition, there was a strong correlation between devices that record sward height and measured pasture yield ( $\mathrm{r}^{2}>92 \%$; O'Donovan et al., 2002b), and there is continuing technology development in this area.

However, an accurate measure of cow genetic merit for milk production is more difficult. The currently accepted standard would be the EBV for milk production traits. However, the EBV is not routinely available, is dependent on lactation length, which is not consistent internationally in genetic evaluation systems, and has poor reliability ( $35 \%$; Mrode, 1996). Cow BW may offer an alternative indicator of cow genetic merit for the purpose of standardizing SR. Although the genetic correlation between $\mathrm{BW}$ and milk production is close to zero, Berry et al. (2003) reported moderate correlations between BW and milk production following adjustment for the confounding effect of BCS.

A comparative SR (CSR) can therefore be defined as the kilograms of BW (at a standard BCS; e.g., at mo 6) per tonne of feed available. Such a definition would allow producers to better calculate the optimum SR for any grazing dairy farm, accounting for known or modeled variations in pasture production, the inclusion of supplementary feeds, and cow BW as a proxy for genetic merit for milk production. The objective of the current study was to evaluate 5 SR over 3 lactations; measure the effect on pasture production and quality, milk production, reproduction, and herd health; and provide the biological information required to calculate the optimum CSR for production and profitability.

\section{MATERIALS AND METHODS}

This experiment was undertaken at No. 2 dairy, DairyNZ (formerly Dexcel), Hamilton, New Zealand $\left(37^{\circ} 47^{\prime} \mathrm{S}, 175^{\circ} 19^{\prime} \mathrm{E}, 40 \mathrm{~m}\right.$ above sea level) between July 1998 and May 2001. The experimental area was a permanent grassland site and pastures were predominantly ryegrass (Lolium perenne L.) and white clover (Trifolium repens L.), on a Te Rapa peaty silt loam soil, a Humic Aquic Haplorthod in soil taxonomy or a Humose Groundwater-Gley Podzol in the New Zealand classification. 


\section{Experimental Design and Treatments}

Ninety-four New Zealand Holstein-Friesian cows were randomly allocated to 1 of $5 \mathrm{SR}(2.2,2.7,3.1,3.7$, and $4.3 \mathrm{cows} / \mathrm{ha}$ ) in a completely randomized design. Treatment farmlets were $8.1,7.3,6.1,4.9$, and 4.5 ha in size, with $18,20,19,18$, and 19 cows, respectively. The SR were chosen to give a wide range either side of what would be considered average for the farming location, which is relative to the amount of pasture it can produce. Cows were allocated ensuring treatment groups were balanced for cow age $(4.4 \pm 2.20 \mathrm{yr})$, BW $(515 \pm 64.2 \mathrm{~kg}), \mathrm{BCS}(4.4 \pm 0.61 ; 1$ to 10 scale; Roche et al., 2004), milk yield from the previous lactation (for multiparous cows; 4,128 $\pm 1,036.1 \mathrm{~kg}$ ), calving date (July $28 \pm 14 \mathrm{~d}$ ), and EBV for milk production (677 \pm $262.9 \mathrm{~kg})$, milk fat $(23.0 \pm 8.69 \mathrm{~kg})$, protein $(20.3 \pm 6.93$ $\mathrm{kg}$ ), and Breeding Worth (a measure of genetic merit accounting for the economic value of the trait; 70 \pm 29.4 ). Assuming an estimated annual pasture production of $18 \mathrm{t}$ of DM/ha, as measured in a previous study on the same farm area (McGrath et al., 1998), the applied SR resulted in an approximate annual feed allowance of 8.1, 6.8, 5.8, 4.9, and $4.2 \mathrm{t}$ of $\mathrm{DM} /$ cow per year.

Thirty-one hectares subdivided into 0.4 -ha paddocks (defined grazing area) were randomly allocated to SR treatment. Five farmlets were established, balanced for geographic location, soil type, distance from the milking parlor, and previous experimental treatments, such that farmlets were evenly spread over the farm in a checkerboard fashion. Each farmlet was then randomly allocated to 1 of the $5 \mathrm{SR}$ treatments. Once farmlets were established they were unchanged throughout the trial.

\section{Trial Management}

Grazing and Fertilizer Management. Although treatments compared a range of SR, grazing management decision rules were the same across farmlets, with the exception of intergrazing interval, which was managed to optimize each individual treatment, and are outlined in detail by Macdonald and Penno (1998). Cows were rotationally grazed similar to the method described by Roche et al. (2007a). Briefly, cows had access to a predetermined allocation of 0.4-ha paddocks (20, $18,15,12$, and 11 paddocks for $2.2,2.7,3.1,3.7$, and 4.3 cows/ha treatments, respectively) and these paddocks were grazed in a rotational order. As a result, cows had access to a fresh allocation of pasture once daily and only returned to the same area when a minimum of 2 leaves had appeared on the majority $(>66 \%)$ of perennial ryegrass (L. perenne L.) tillers (approximately $2,500 \mathrm{~kg}$ of DM/ha in spring, 4,000 kg of DM/ha in summer, and $3,000 \mathrm{~kg}$ of $\mathrm{DM} / \mathrm{ha}$ in autumn and winter; all measure- ments to ground level). Desired postgrazing residual in all treatments was $40 \mathrm{~mm}$.

Grazing management was determined by weekly monitoring of farm pasture cover. The total farmlet area was available for grazing for the entire year. However, pasture surplus to requirements was conserved as silage when growth rates exceeded cow requirements (primarily October and November). All pasture was conserved in bales ( $220 \mathrm{~kg}$ of $\mathrm{DM} \pm 49.6$ ), with silage from each farmlet kept separately for use on that farmlet. A sample of the pasture was taken before baling for DM determination, and bales were weighed from each paddock to give an estimate of the amount of feed conserved from each paddock. Mechanical cutting (topping) of pasture residuals in midseason occurred as deemed necessary to maintain pasture quality.

The farmlets received annual "maintenance" dressings of $54 \mathrm{~kg}$ of $\mathrm{P} / \mathrm{ha}$ and $55 \mathrm{~kg}$ of $\mathrm{S} / \mathrm{ha}$ as single superphosphate in March and $50 \mathrm{~kg}$ of $\mathrm{K} / \mathrm{ha}$ as muriate of potash in November. If conserved silage was made from an area, an additional $50 \mathrm{~kg}$ of $\mathrm{K} / \mathrm{ha}$ was applied. In addition, $200 \mathrm{~kg}$ of N/ha was applied (in 4 to 5 applications) annually to each farmlet.

Animal Management. Cows on all farmlets were managed in a similar manner. The system of milk production was seasonal, with approximately $50 \%$ of cows calving in $2 \mathrm{wk}, 40 \%$ calving in the next $4 \mathrm{wk}$, and the remaining cows calving during wk 7 and 8 . Cows with a due calving date later than wk 8 of the seasonal calving period were hormonally induced to calve during wk 7 and 8 using a 2-step combination of dexamethasone (Opticortenol S, Novartis Animal Health, Switzerland; Voren, Boehringer-Ingelheim, Berkshire, UK) and prostaglandin (Estrumate, Schering-Plough Coopers, New Zealand), provided they had low SCC before dryoff $(<200,000$ cell s $/ \mathrm{mL})$, were in a BCS of 5.0 or greater (on a 10-point scale), and blood $\mathrm{Mg}(>0.8 \mathrm{mmol} / \mathrm{L})$ and $\gamma$-glutamyl transferase ( 15 to $22 \mathrm{U} / \mathrm{L}$ plasma) measured the week before planned induction did not indicate health concerns.

The routine mating management policy at No. 2 Dairy was to record any cows exhibiting signs of estrus before the planned start of mating (PSM). Estrous detection was performed by twice-daily visual observation of estrous behavior with the aid of paint applied to the tail-head of the cow. Cows not detected in estrus by PSM were presented for veterinary examination. Those without a palpable corpus luteum were treated with an intravaginal controlled internal drug releasing insert (InterAg, Hamilton, New Zealand) according to the Genermate program (Cliff et al., 1995). Artificial insemination was performed for the first 6 wk from PSM, followed by a further 6 wk of natural breeding. Pregnancy diagnosis was performed by manual palpation 
of uterine contents at least $5 \mathrm{wk}$ after the end of the 12 -wk mating period.

At the end of each lactation, approximately $20 \%$ of the cows from each farmlet was culled on the basis of reproductive failure, health, age, and genetic merit, and were replaced with primiparous cows 1 mo before the planned start of calving. Age structure did not differ across farmlets for the duration of the study. Lactation was curtailed for individual cows within each season, based on BCS, level of production, and number of days from calving, as described by Macdonald and Penno (1998).

Animal Health. Because of low pasture Mg and relatively high $\mathrm{K}$ and $\mathrm{N}$ concentrations in pasture during winter and spring, $\mathrm{Mg}$ supplementation was routinely practiced to prevent hypomagnesemia and associated hypocalcemia (Roche and Berry, 2006). Magnesium oxide was top dressed on pastures grazed by the nonlactating cows from $3 \mathrm{wk}$ before planned start of calving until calving was completed. After calving, all lactating cows received $20 \mathrm{~g} \mathrm{Mg}$ daily as an oral supplement of magnesium chloride $\left(\mathrm{MgCl}_{2} \cdot 6 \mathrm{H}_{2} \mathrm{O}\right)$ at the a.m. milking until late November when $\mathrm{Mg}$ supplementation ceased. During periods of increased risk of bloat, an antibloating solution (Pluronic, Ecolab, Hamilton, New Zealand) was also provided at the morning milking. Zinc sulfate (3.6 $\mathrm{g}$ of $\mathrm{ZnSO}_{4} \cdot 7 \mathrm{H}_{2} \mathrm{O} / 100 \mathrm{~kg}$ of $\mathrm{BW}$ ) was given orally to the cows during periods of increased vulnerability to facial eczema, as determined by fungal (Pithomyces chartarum) spore counts. Water troughs were located in each paddock so that cows had continual access to water.

\section{Measurements}

Pasture Measurement. Pasture herbage mass was estimated by 2 people by calibrated visual assessment of each paddock from a weekly farm walk similar to the method described by O'Donovan et al. (2002a). On each occasion, 11 calibration quadrats (each $0.3 \mathrm{~m}^{2}$ ) covering the range of herbage mass present were assessed before and after the farm walk. After the final assessment, the pasture within the quadrats was cut to ground level, washed, and dried in a forced-draft oven at $100^{\circ} \mathrm{C}$ until dry (approximately $48 \mathrm{~h}$ ). The herbage mass estimate for each paddock (for that week) was then adjusted using a regression of quadrat visual assessment on quadrat herbage mass. The net herbage accumulation was calculated weekly from the increase in herbage mass on ungrazed paddocks. Throughout the trial, one assessor, calibrated in the manner outlined previously, visually assessed pasture mass pre- and postgrazing as outlined by O'Donovan et al. (2002a).
Those data were used to estimate total pasture consumed per hectare per year.

Representative samples of pasture were hand-clipped to grazing height (to represent what the cows would be consuming) from paddocks due to be grazed on each farmlet on one day each month. Representative samples of pasture silage were taken just before feeding. Duplicate samples of all feeds were dried at either $100^{\circ} \mathrm{C}$ for DM analysis, or at $60^{\circ} \mathrm{C}$ for analysis of nutrient composition. All samples dried at $60^{\circ} \mathrm{C}$ were dried for $72 \mathrm{~h}$, ground to pass through a $1.0-\mathrm{mm}$ sieve (Christy Lab Mill, Suffolk, UK) and analyzed for CP, NDF, ADF, NSC, lipid, and ash by near infrared spectroscopy (Corson et al., 1999). The ME content was derived directly from predicted OM digestibility on the basis of an in vitro cellulase digestibility assay, which had been calibrated against in vivo standards (Corson et al., 1999). Mineral concentrations were determined by inductively coupled plasma emission spectroscopy.

Milk, BCS, and BW. Individual cow milk yields were recorded weekly (Tru-Test milk meter system, Palmerston North, New Zealand). Milk fat, CP, true protein, casein, and lactose concentrations determined on composite p.m. and a.m. aliquot samples by Fossomatic FT120 (Foss Electric, Hillerød, Denmark). Milk component data were verified by reference techniques for a subset of milk samples [milk fat: Röse-Gottlieb (IDF, 1987); CP, true protein, and casein: macro-Kjeldahl techniques (Barbano et al., 1991)].

Body weight and BCS were determined every other week following the a.m. milking or at approximately $0900 \mathrm{~h}$ during the nonlactating period. Body condition score was assessed pre- and postcalving on a 10-point scale, where 1 is emaciated and 10 is obese (Roche et al., 2004). Those scores can be converted to the 5-point scale using the regression equation generated by Roche et al. $(2004 ; 5$-point scale $=1.5+0.32 \times 10$-point scale $)$. Calving BW and calf birth weight were recorded within $18 \mathrm{~h}$ of calving.

Lactation Profiles. Preliminary graphical analysis of the mean milk yield lactation curve and individual cow lactation curves revealed a profile similar to that described by the Wilmink exponential function (Wilmink, 1987) and recently presented by Roche et al. (2006) for grazing dairy cows. Although a similar shaped profile was observed for FCM, fat, protein, and lactose yield, it was not as consistent across individual lactations. Therefore, the Wilmink exponential function was fitted to only milk test-day yields within lactation and is described as follows:

$$
y_{t}=a+b \times e^{-0.05 t}+c \times t .
$$

In this model, $y_{t}$ represents yield $(\mathrm{kg})$ at day $t$ of lactation, and $a, b$, and $c$ are estimated parameters 
relating to the height of the curve, the initial phase of postcalving incline to peak, and the subsequent postpeak decline phase, respectively. The regression parameters were estimated for each cow-lactation separately using PROC NLIN (SAS Institute, 2006). The first derivate of the Wilmink function with respect to time $(d Y$ / $d t$ ) for each cow-lactation was set equal to zero and solved for DIM to determine DIM at peak yield; DIM was rounded to the nearest whole integer. Peak yield was the yield corresponding to DIM at peak, and the final milk yield measure was regarded as the final DIM for that lactation. Total lactation milk yield was derived as the definite integral of the function for each lactation, and 305-d lactation yield was estimated by setting last DIM to 305 for all cows.

DMI. Individual animal intake estimates were obtained at pasture using the $n$-alkane technique as modified by Dillon and Stakelum (1989). Briefly, each cow was dosed twice daily (at milking) for a 10-d period with a pellet containing $356 \mathrm{mg}$ of $n$-dotriacontane (C32; i.e., $712 \mathrm{mg}$ of $\mathrm{C} 32 / \mathrm{cow}$ per d) on 4 occasions in each lactation. Fecal grab samples were collected twice daily from each cow (after milking) during the last $5 \mathrm{~d}$ of the 10-d period. The fecal samples from each cow for the 5 -d period were then bulked and stored at $-17^{\circ} \mathrm{C}$ until alkane analysis. During the same 5-d period, pasture samples were "plucked" to grazing height, following close observation of the grazing animal, to represent pasture grazed. The $n$-alkane contents (C25 to C36) of the pasture and feces were analyzed by gas chromatography.

The ratio of herbage C33 (tritriacontane) to dosed C32 (n-dotriacontane) was used to estimate intake. Estimates of daily herbage intake were calculated as follows:

$$
\begin{aligned}
& \text { Daily pasture DMI }(\mathrm{kg} / \mathrm{cow})= \\
& \frac{F_{i} / F_{j} \times\left(D_{j}+I_{s} \times S_{j}\right)-I_{s} \times S_{i}}{P_{i}-\left(P_{j} \times F_{i} / F_{j}\right)}
\end{aligned}
$$

where $F_{i}, S_{i}$, and $P_{i}$ are the concentrations $(\mathrm{mg} / \mathrm{kg}$ of $\mathrm{DM}$ ) of the natural odd-chain $n$-alkane (C33) in feces, supplement, and pasture, respectively; $F_{j}, S_{j}$, and $P_{j}$ are the concentrations $(\mathrm{mg} / \mathrm{kg}$ of $\mathrm{DM})$ of the dosed evenchain $n$-alkane (C32) in feces, supplements, and pasture, respectively; $I_{S}$ is the daily supplement intake, and $D_{j}$ is the dose rate $(\mathrm{mg} / \mathrm{d})$ of the even-chain $n$-alkane (C32).

\section{Statistical Analyses}

For each year, cumulative milk and FCM yield and yield of milk components were calculated for each cow as the sum of yields from calving to the end of lactation.
Average lactation fat, protein, and lactose percentages were also calculated as the average of all test-day records during lactation. Body weight and BCS were averaged across the intercalving period. One mean was calculated for each variable for each farmlet. Average DMI was calculated for each farmlet for the 4 periods of the year during which DMI was estimated. Reproduction variables were as defined by Roche et al. (2007a) and averages calculated for each treatment.

Cumulative pasture production was estimated for each paddock annually and the treatment average calculated. The average of all of the quality variables measured was calculated as the average of monthly measurements.

All data were averaged across years to provide one value per farmlet and analyzed by ANOVA using the statistical procedures of Genstat, with SR as the fixed effect. Linear and quadratic contrasts of SR were included in the model.

\section{RESULTS AND DISCUSSION}

Previous research investigating the effect of SR in grazing systems on milk production per cow and per hectare did not allow us to predict the effect of SR change. The research in question was either short-term and unable to account for the complete farm system (Castle et al., 1968; Baker and Leaver, 1986; Kennedy et al., 2006), was undertaken more than $30 \mathrm{yr}$ ago (McMeekan, 1956; Foot and Line, 1960; Castle et al., 1968; Gordon, 1973), and considering the advances in cow genetics and farm management over that time, may no longer be applicable; or they merely compared "high" vs. "low" SR treatments, making it impossible to determine an optimum SR for any production system or to extend their results beyond the system investigated (Foot and Line, 1960; Castle et al., 1968; Gordon, 1973; Dillon et al., 1995).

\section{CSR}

An additional limitation of previous data is that the reported experiments involve cows differing in genetic merit for milk production and farm systems in which pasture production per hectare and supplementary feed amounts can be greatly different. Both of these factors are likely to modify the effect of SR. The current study evaluated 5 different SR over 3 years, providing data on the effect of SR on pasture production and quality variables, enabling the provision of a more robust and extendable definition of SR, termed CSR. We defined CSR as kilograms of BW (at a standard BCS; e.g., at mo 6) per tonne of feed available. Considering that all treatment herds in the current study were balanced 
Table 1. Effect of stocking rate on farm characteristics for farmlets stocked at 2.2, 2.7, 3.1, 3.7 or 4.3 cows/ha over a 3-yr period

\begin{tabular}{|c|c|c|c|c|c|c|c|}
\hline \multirow[b]{2}{*}{ Item } & \multicolumn{5}{|c|}{ Stocking rate } & \multicolumn{2}{|c|}{$P$-value } \\
\hline & 2.2 & 2.7 & 3.1 & 3.7 & 4.3 & Linear & Quadratic \\
\hline Pasture grown, $\mathrm{kg}$ of $\mathrm{DM} / \mathrm{ha}$ per $\mathrm{yr}$ & 18,048 & 18,050 & 19,484 & 18,538 & 20,394 & 0.11 & 0.74 \\
\hline Postgrazing mass, $\mathrm{kg}$ of $\mathrm{DM} / \mathrm{ha}$ & 2,265 & 2,022 & 1,985 & 1,836 & 1,766 & $<0.001$ & 0.13 \\
\hline \multicolumn{8}{|l|}{ Grazing interval, $\mathrm{d}$} \\
\hline Winter & 58.1 & 66.3 & 70.2 & 68.9 & 76.9 & $<0.05$ & 0.12 \\
\hline Spring & 31.3 & 30.5 & 29.8 & 33.0 & 31.6 & 0.47 & 0.77 \\
\hline Pasture consumed, $\mathrm{kg}$ of $\mathrm{DM} / \mathrm{ha}$ per $\mathrm{yr}$ & 12,098 & 13,785 & 14,322 & 15,609 & 16,597 & $<0.01$ & 0.22 \\
\hline Pasture consumed, $\mathrm{kg}$ of $\mathrm{DM} /$ cow per yr & 5,438 & 5,018 & 4,575 & 4,214 & 3,887 & $<0.01$ & 0.11 \\
\hline Conserved pasture, $\mathrm{kg}$ of $\mathrm{DM} / \mathrm{ha}$ per $\mathrm{yr}$ & 1,257 & 1,078 & 806 & 306 & 65 & $<0.01$ & $<0.01$ \\
\hline Conserved pasture, $\mathrm{kg}$ of $\mathrm{DM} / \mathrm{cow}$ per $\mathrm{yr}$ & 566 & 394 & 258 & 83 & 15 & $<0.01$ & $<0.05$ \\
\hline Silage consumed, $\mathrm{kg}$ of $\mathrm{DM} / \mathrm{ha}$ per $\mathrm{yr}$ & 354 & 543 & 562 & 812 & 876 & $<0.01$ & $<0.05$ \\
\hline Silage consumed, $\mathrm{kg}$ of $\mathrm{DM} / \mathrm{ha} /$ cow per $\mathrm{yr}$ & 159 & 198 & 180 & 219 & 205 & 0.12 & 0.29 \\
\hline Purchased supplements, $\mathrm{kg}$ of $\mathrm{DM} / \mathrm{ha}$ per $\mathrm{yr}$ & 0 & 0 & 0 & 506 & 812 & $<0.05$ & 0.07 \\
\hline
\end{tabular}

for cow BW at the beginning of the study, the CSR equivalent to the SR imposed would be $62,76,90,103$, and $120 \mathrm{~kg}$ of BW/t of DM per year for $2.2,2.7,3.1,3.7$, and $4.3 \mathrm{cows} / \mathrm{ha}$, respectively, assuming no feeds were acquired externally to the grazing platform and 18.0 $\mathrm{t}$ of DM pasture was grown/ha per year (McGrath et al., 1998).

\section{Pasture Production and Quality}

Table 1 highlights some of the changes in farm management that occur as SR changes and the effect of SR on the amount of pasture grown and consumed. The effect of SR on key pasture quality characteristics are presented in Table 2. Pasture grown tended $(P=0.11)$ to increase linearly with increasing SR, partly offsetting the decline in available pasture per cow. This resulted in a smaller increase in CSR than was originally expected. Actual CSR were 60, 70, 76, 89, and 91 $\mathrm{kg}$ of BW/t of DM for 2.2, 2.7, 3.1, 3.7, and 4.3 cows/ha, respectively, using the $\mathrm{BW}$ of the cows in mo 6 . This is equivalent to an annual allowance of $8.2,6.7,6.3,5.1$, and $4.9 \mathrm{t}$ of $\mathrm{DM} / \mathrm{cow}$, respectively. In addition to the tendency for an increase in pasture grown per hectare with increasing SR, postgrazing residual mass also declined linearly, reflecting an increase in pasture utilization rates with increasing SR that is consistent with the linear increase in pasture consumed per hectare. These data indicate less of a difference in annual pasture allocation than would be reflected in either SR or CSR. There was a 4 and $3 \mathrm{t}$ of $\mathrm{DM} /$ cow difference in the amount of pasture available to the highest and lowest stocked treatments if compared on a SR and CSR basis, respectively. However, measured pasture disappearance (the accumulated difference between pre- and postgrazing pasture masses across the year) and the amount of pasture conserved for silage suggests that the actual difference in pasture harvested at the highest and lowest SR was $2.1 \mathrm{t}$ of DM/cow, and the difference in actual pasture consumed was approximately $1.5 \mathrm{t}$ of $\mathrm{DM} /$ cow. Therefore, the decline in utilizable pasture with increasing SR was not as dramatic as would have been predicted. There were insufficient detailed measurements of pasture production in the previous studies investigating SR to have been able to determine this effect on the availability of utilizable pasture.

There are sound physiological reasons why the numerical difference in net pasture grown per hectare with increasing SR is real, including differences in grazing interval (i.e., the average number of days between successive grazing events) and postgrazing residual. There was an interaction $(P<0.001)$ between SR and season of year in grazing interval, with grazing interval increasing linearly with increasing SR in winter, summer, and autumn, but not spring. Perennial ryegrass dominant pastures, as used in the current study, tend to follow a sigmoidal pattern of growth (Voisin, 1959), beginning slowly before increasing exponentially until the complete emergence of the third live leaf. At this point, leaf senescence equals emergence and there is little additional net growth of leaf. Therefore, a greater intergrazing interval will result in greater annual production of pasture. This is consistent with the greater pasture production with the generally longer intergrazing intervals as SR rate increased. The lack of a difference in grazing interval in spring is also consistent with this physiological response of the plant to grazing interval. Figure 1 depicts the average pasture accumulation and pasture DMI per hectare of the 5 farmlets over the 3 years. During spring (mo 3, 4, and 5), pasture 
Table 2. Effect of stocking rate $^{1}$ on average pasture quality ${ }^{2}$ characteristics (\% of DM), ME concentration (MJ of ME/kg of DM), and mineral (\% of DM) and trace element concentration ( $\mathrm{mg} / \mathrm{kg}$ of DM)

\begin{tabular}{|c|c|c|c|c|c|c|c|}
\hline \multirow[b]{2}{*}{ Item } & \multicolumn{5}{|c|}{ Stocking rate } & \multicolumn{2}{|c|}{$P$-value } \\
\hline & 2.2 & 2.7 & 3.1 & 3.7 & 4.3 & Linear & Quadratic \\
\hline $\mathrm{CP}$ & 22.1 & 22.6 & 22.1 & 22.3 & 22.8 & 0.28 & 0.55 \\
\hline Lipid & 4.8 & 4.2 & 4.2 & 4.3 & 4.3 & 0.36 & 0.23 \\
\hline Ash & 10.9 & 10.9 & 10.7 & 10.7 & 10.9 & 0.72 & 0.35 \\
\hline $\mathrm{ADF}$ & 24.4 & 23.6 & 23.4 & 22.9 & 22.7 & $<0.01$ & $<0.01$ \\
\hline NDF & 44.4 & 43.3 & 43.0 & 42.4 & 41.5 & $<0.01$ & $<0.05$ \\
\hline $\mathrm{NSC}$ & 10.1 & 10.4 & 10.8 & 11.0 & 10.7 & 0.13 & 0.06 \\
\hline OM digestibility & 76.3 & 77.7 & 78.2 & 78.8 & 79.0 & $<0.05$ & $<0.01$ \\
\hline ME & 11.0 & 11.2 & 11.3 & 11.4 & 11.4 & $<0.05$ & $<0.001$ \\
\hline $\mathrm{P}$ & 0.39 & 0.39 & 0.37 & 0.38 & 0.38 & 0.38 & 0.49 \\
\hline $\mathrm{S}$ & 0.34 & 0.33 & 0.33 & 0.34 & 0.34 & 0.59 & 0.45 \\
\hline $\mathrm{Mg}$ & 0.19 & 0.18 & 0.19 & 0.18 & 0.20 & 0.51 & 0.42 \\
\hline $\mathrm{Na}$ & 0.13 & 0.13 & 0.17 & 0.14 & 0.15 & 0.49 & 0.67 \\
\hline $\mathrm{Ca}$ & 0.47 & 0.46 & 0.46 & 0.46 & 0.47 & 0.93 & $<0.05$ \\
\hline $\mathrm{K}$ & 3.5 & 3.5 & 3.4 & 3.5 & 3.6 & 0.38 & 0.22 \\
\hline $\mathrm{Mn}$ & 100.5 & 103.8 & 99.7 & 91.8 & 98.2 & 0.31 & 0.64 \\
\hline $\mathrm{Zn}$ & 49.4 & 51.8 & 48.5 & 46.1 & 49.2 & 0.46 & 0.75 \\
\hline $\mathrm{Cu}$ & 7.7 & 7.4 & 8.5 & 7.8 & 8.1 & 0.50 & 0.80 \\
\hline Co & 0.08 & 0.10 & 0.10 & 0.07 & 0.09 & 0.82 & 0.93 \\
\hline
\end{tabular}

${ }^{1}$ Farms were stocked at $2.2,2.7,3.1,3.7$, or $4.3 \mathrm{cows} / \mathrm{ha}$. The experiment was undertaken over a 3 -yr period.

${ }^{2}$ Pasture was sampled monthly.

production vastly exceeded requirements and so there was little need for longer intergrazing intervals (i.e., are not affected by SR). In comparison, during late summer, autumn, and winter there was a deficit of pasture grown relative to requirements. This deficit increased with increasing SR and was partially alleviated by longer rotations. Therefore, increasing the intergrazing interval and capturing the advantage of additional pasture grown is an essential element of managing increasing SR.

A further factor contributing to an increase in pasture production with increasing SR could be the decreased

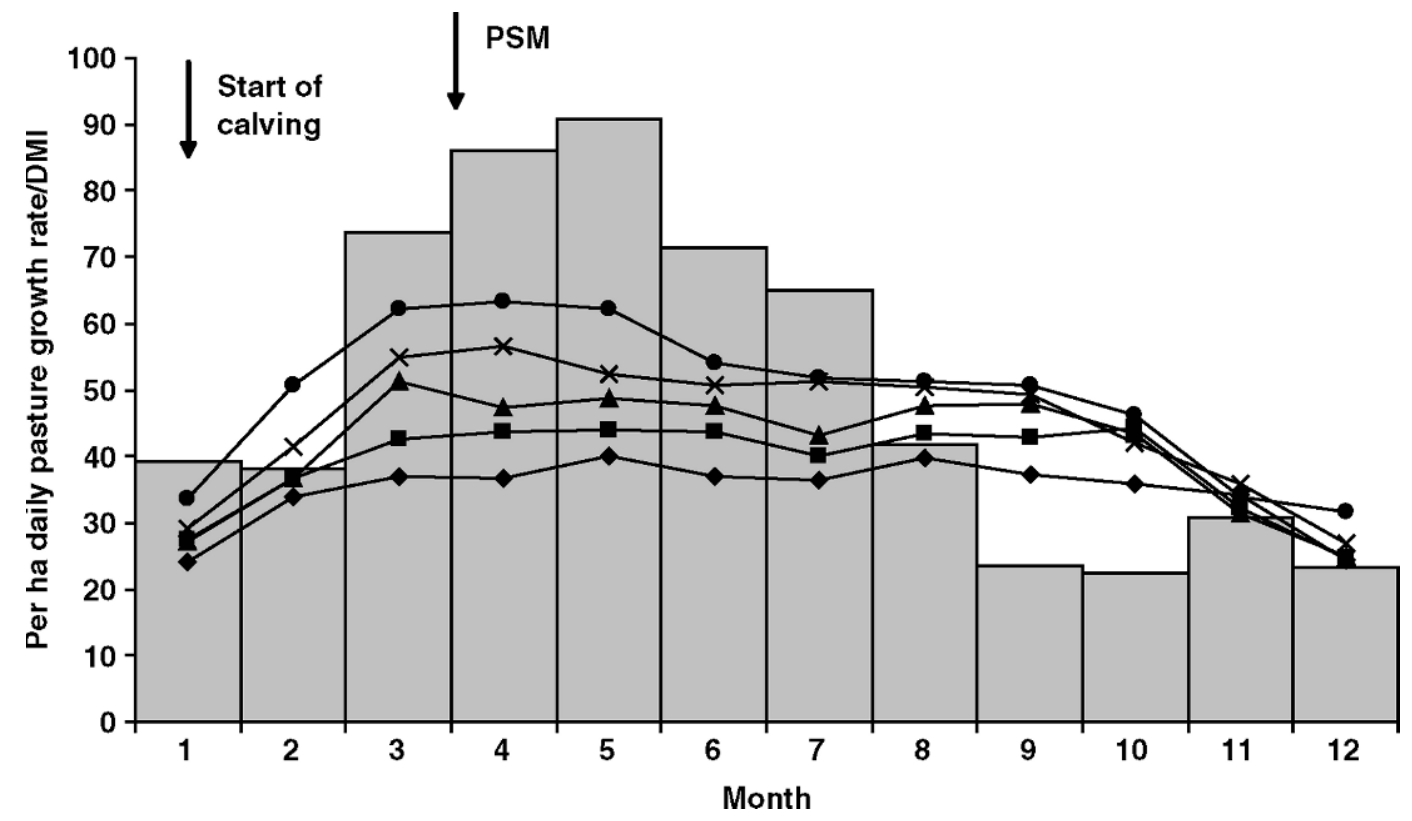

Figure 1. Daily pasture growth rate (vertical bars; kg of DM/ha per d) and DMI (kg of DM/ha per d) of dairy cows stocked at 2.2 ( $\bullet$ ), $2.7(\mathbf{\square}), 3.1(\mathbf{\Lambda}), 3.7(\times)$, and $4.3(\bullet)$ cows/ha over a 3-yr period. Months 1 to 12 refer to the southern hemisphere pasture growth season of July to June. PSM = planned start of mating. 
pasture-residual mass (i.e., the amount of pasture remaining following grazing). Grass plants need periodic close defoliation to renew photosynthetic efficiency and to prevent shading of tiller bases. Based on a number of studies, Hunt and Brougham (1967) reported that where repeated lax defoliation of perennial ryegrass left enough herbage to intercept $95 \%$ of incident light, the amount of green leaf and the number of tillers initiated progressively declined, while the proportion of dead material increased. Consistent with this, Lee et al. (2008) reported a quadratic effect of postgrazing residual mass on pasture growth, with pasture production declining at low and high residuals. Lee et al. (2007) reported no negative effect of grazing pastures to $1,260 \mathrm{~kg}$ of $\mathrm{DM} / \mathrm{ha}$ residuals (measured to ground level) on subsequent pasture production, suggesting that residuals must be below this to compromise pasture growth. Residuals were greater than this on even the highest stocked treatments in the current study.

The effect of lower grazing residuals with increasing $\mathrm{SR}$ is also manifested in the average pasture quality characteristics presented in Table 2 . The increasing $\mathrm{SR}$ and the associated decline in postgrazing pasture residual mass resulted in a quadratic decline in NDF and $\mathrm{ADF}$ concentrations and a quadratic increase in OM digestibility, NSC, and ME. So, in general, it can be said that management changes associated with increased SR result in an improvement in pasture quality. This is despite the longer grazing interval and associated advancement in pasture maturity, and the greater amount of mechanical cutting that was undertaken in the lower stocked farmlets (Table 1). Fales et al. (1995) also reported increased pasture quality with higher SR, and Lee et al. (2007) reported a lower NDF and ADF and higher OM digestibility, NSC, and ME in swards that had been grazed more severely in the previous grazing; the result is an effect of a greater proportion of live leaf and less senescent material.

\section{Milk Production, BW, and BCS}

The effect of SR on DMI and milk production per cow and per hectare, and the estimated parameters of the lactation profile are presented in Tables 3 and 4, respectively; Figure 2 depicts the effect of SR on the shape of the lactation profile. The median $\mathrm{R}^{2}$ obtained from fitting the Wilmink function to the milk yield data was 0.84. All of the per-cow milk production variables, with the exception of fat and lactose percentage, declined linearly with increasing SR. The quadratic tendency for a decline in milk fat percentage can probably be attributed to the lower BCS at calving (Roche et al., $2007 \mathrm{~b}$ ) and the decline in protein percentage a result of lower energy intakes in early lactation (Spörndly,
1989). The linear decline in the per-cow yield of milk, FCM, and milk components was caused by both the shortening lactation length (Table 3$)$ and the lower $(P=$ 0.06 ) peak and poorer persistency ( $c$ parameter; $P<$ 0.05 ) with increasing SR (Table 4 and Figure 2). The published effect of SR on milk yield is not consistent. A recent study (Kennedy et al., 2006) compared a high and medium SR and reported a negative effect of SR on milk and milk component yield and milk protein percentage, consistent with the findings reported here. Similarly, earlier studies (Castle et al., 1968; Gordon, 1973) reported a negative effect of SR on milk yield per cow, but a positive effect on milk yield per hectare. However, the 2 most recent comprehensive studies evaluating the effect of SR showed only a very small $(\sim 100$ $\mathrm{kg}$ of milk; Dillon et al. 1995) or no effect (Fales et al., 1995) of SR on milk yield. However, in the study of Fales et al. (1995), concentrates were fed in proportion to milk production $(0.25 \mathrm{~kg}$ of grain $/ \mathrm{kg}$ of milk, with a minimum of $4 \mathrm{~kg}$ of $\mathrm{DM} / \mathrm{d}$ ), effectively removing the negative effect of the SR-imposed feed restriction in early lactation. Similarly, the comparison published by Dillon et al. (1995) delayed the calving date by $7 \mathrm{wk}$ and then compared high vs. low SR; the later calving date in effect removed the early-lactation feed deficit associated with the higher SR (Figure 1). In addition, neither system was purely grazing, with both requiring confinement during early and late lactation and including a strategy of supplementing cows with purchased supplements when sufficient pasture was not available. Similarly, the short-term SR comparison of Baker and Leaver (1986) included a supplementation strategy that was altered weekly to maintain desired grazing residuals.

Data presented here indicate that increasing SR reduces the availability of pasture for cows during autumn and winter; thereby, negatively impacting on peak milk yield and total lactation yield. Strategies to overcome this depression in per-cow production include the provision of purchased supplements of at least as high a quality as pasture during the periods of feed deficit or delaying calving such that the early lactation period of feed deficit is removed. This would, however, increase the amount of pasture to be conserved as silage, because maximum intakes would no longer coincide with peak pasture growth rates. These inconsistencies on the reported effect of SR on milk production are further argument for the benefit of a more robust measure of SR that accounts for cow type (size), pasture grown, and supplements sourced externally to the grazing area. One such option is the previously defined CSR. In the present study, CSR explained very little additional variation in milk production variables $(<5 \%)$ when compared with SR. However, all treatments were 
Table 3. Lactation length (d), pasture DMI, ${ }^{1}$ annual milk production per cow and per ha $(\mathrm{kg})$, average milk composition (\%), calving BCS (1 to 10 scale), BW (kg), and calf birth weight (kg) of dairy cows stocked at either $2.2,2.7,3.1,3.7$, or 4.3 cows/ha over a 3 -yr period

\begin{tabular}{|c|c|c|c|c|c|c|c|}
\hline \multirow[b]{2}{*}{ Item } & \multicolumn{5}{|c|}{ Stocking rate } & \multicolumn{2}{|c|}{$P$-value } \\
\hline & 2.2 & 2.7 & 3.1 & 3.7 & 4.3 & Linear & Quadratic \\
\hline Lactation length, $d$ & 291 & 274 & 258 & 234 & 221 & $<0.001$ & 0.74 \\
\hline \multicolumn{8}{|c|}{ Pasture DMI, kg/cow per d } \\
\hline Winter & 9.0 & 6.8 & 6.2 & 5.8 & 5.0 & $<0.05$ & $<0.05$ \\
\hline Spring & 14.4 & 13.5 & 13.8 & 13.9 & 13.2 & 0.20 & 0.52 \\
\hline Summer & 12.5 & 13.3 & 10.7 & 11.8 & 13.9 & 0.70 & 0.49 \\
\hline Autumn & 9.3 & 8.1 & 9.1 & 9.1 & 8.0 & 0.48 & 0.78 \\
\hline \multicolumn{8}{|c|}{ Annual production per cow, $\mathrm{kg}$} \\
\hline Milk & 5,032 & 4,351 & 4,128 & 3,616 & 3,448 & $<0.01$ & 0.07 \\
\hline FCM & 5,473 & 4,835 & 4,532 & 3,981 & 3,636 & $<0.001$ & 0.06 \\
\hline Fat & 231 & 206 & 192 & 169 & 150 & $<0.01$ & $<0.05$ \\
\hline Protein & 176 & 154 & 146 & 126 & 115 & $<0.01$ & 0.15 \\
\hline Lactose & 244 & 211 & 202 & 177 & 168 & $<0.01$ & 0.11 \\
\hline $\mathrm{NE}_{\mathrm{L}}, \mathrm{MJ}$ & 17,271 & 15,218 & 14,295 & 12,518 & 11,423 & $<0.01$ & 0.08 \\
\hline \multicolumn{8}{|c|}{ Annual production per ha, $\mathrm{kg}$} \\
\hline Milk & 11,071 & 11,747 & 12,796 & 13,380 & 14,828 & $<0.01$ & 0.69 \\
\hline FCM & 12,040 & 13,055 & 14,048 & 14,728 & 15,634 & $<0.001$ & 0.18 \\
\hline Fat & 507 & 557 & 595 & 625 & 647 & $<0.01$ & $<0.05$ \\
\hline Protein & 388 & 415 & 452 & 467 & 494 & $<0.01$ & 0.31 \\
\hline Lactose & 537 & 570 & 626 & 653 & 723 & $<0.001$ & 0.83 \\
\hline $\mathrm{NE}_{\mathrm{L}}, \mathrm{MJ}$ & 37,995 & 41,090 & 44,314 & 46,315 & 49,117 & $<0.01$ & 0.20 \\
\hline \multicolumn{8}{|l|}{ Milk composition, $\%$} \\
\hline Fat & 4.59 & 4.75 & 4.67 & 4.69 & 4.37 & 0.12 & 0.08 \\
\hline Protein & 3.51 & 3.54 & 3.53 & 3.49 & 3.33 & $<0.05$ & $<0.05$ \\
\hline Lactose & 4.85 & 4.86 & 4.91 & 4.89 & 4.88 & 0.34 & 0.23 \\
\hline Calving BW & 487 & 463 & 460 & 452 & 442 & $<0.05$ & 0.49 \\
\hline Calving BCS & 4.7 & 4.4 & 4.2 & 4.3 & 4.2 & $<0.01$ & 0.77 \\
\hline Calf birth weight & 37.9 & 36.6 & 37.5 & 37.2 & 38.5 & 0.40 & 0.19 \\
\hline
\end{tabular}

${ }^{1}$ DMI was measured using the n-alkane technique (Dillon and Stakelum, 1989).

balanced for soil type, location on the research farm, soil fertility, and distance from the milking facility. Therefore, one would expect each farm to be near identical, with the potential to produce similar amounts of feed. In such a situation, CSR would not be expected to offer significant advantages over SR. However, that CSR did explain slightly more of the variation in milk yield per cow associated with SR when changes to SR

Table 4. Effect of stocking rate ${ }^{1}$ on estimated milk yield parameters from the Wilmink exponential function, ${ }^{2}$ and the associated derived peak milk yield (kg/d), DIM to peak, ${ }^{3}$ lactation milk yield, and 305-d milk yield ${ }^{4}$

\begin{tabular}{lllllllll}
\hline & \multicolumn{9}{c}{ Stocking rate } & & \multicolumn{2}{c}{$P$-value } \\
\cline { 2 - 5 } Item & 2.2 & 2.7 & 3.1 & 3.7 & 4.3 & & Linear & Quadratic \\
\hline$a$ & 27.7 & 25.3 & 25.4 & 24.6 & 24.7 & & 0.09 & 0.09 \\
$b$ & -7.303 & -6.656 & -10.774 & -8.306 & -9.633 & & 0.34 & 0.65 \\
$c$ & -0.0678 & -0.0659 & -0.0697 & -0.0711 & -0.0738 & & $<0.05$ & 0.13 \\
Peak milk & 23.7 & 21.1 & 21.3 & 20.2 & 20.2 & & 0.06 & 0.09 \\
DIM to peak & 46.9 & 45.2 & 44.4 & 49.3 & 42.4 & & 0.61 & 0.82 \\
Lactation yield & 5,109 & 4,365 & 4,016 & 3,579 & 3,401 & & $<0.01$ & $<0.01$ \\
305-d milk yield & 5,161 & 4,531 & 4,306 & 3,998 & 3,865 & & $<0.01$ & $<0.01$ \\
\hline
\end{tabular}

${ }^{1}$ Dairy cows were stocked at $2.2,2.7,3.1,3.7$ or 4.3 cows/ha. The experiment was undertaken over a 3 yr period.

${ }^{2}$ The estimated parameters $a, b$, and $c$ are from the Wilmink (1987) lactation function, where $a$ relates to the height of the curve, $b$ the initial phase of postcalving incline, and $c$ the postpeak decline phase. The function is described as $Y_{t}=a+b \times e^{-0.05 t}+c \times t$, where $Y_{t}$ represents yield (kg) at day $t$ of lactation.

${ }^{3}$ The first derivate of the Wilmink function with respect to time $(d Y / d t)$ was set equal to zero and solved for DIM to determine DIM at peak yield; DIM was rounded to the nearest whole integer. Peak yield was the yield corresponding to DIM at peak.

${ }^{4} 305$-d milk yield was estimated from the Wilmink (1987) function after setting lactation length to 305 $\mathrm{d}$ for all herds. 


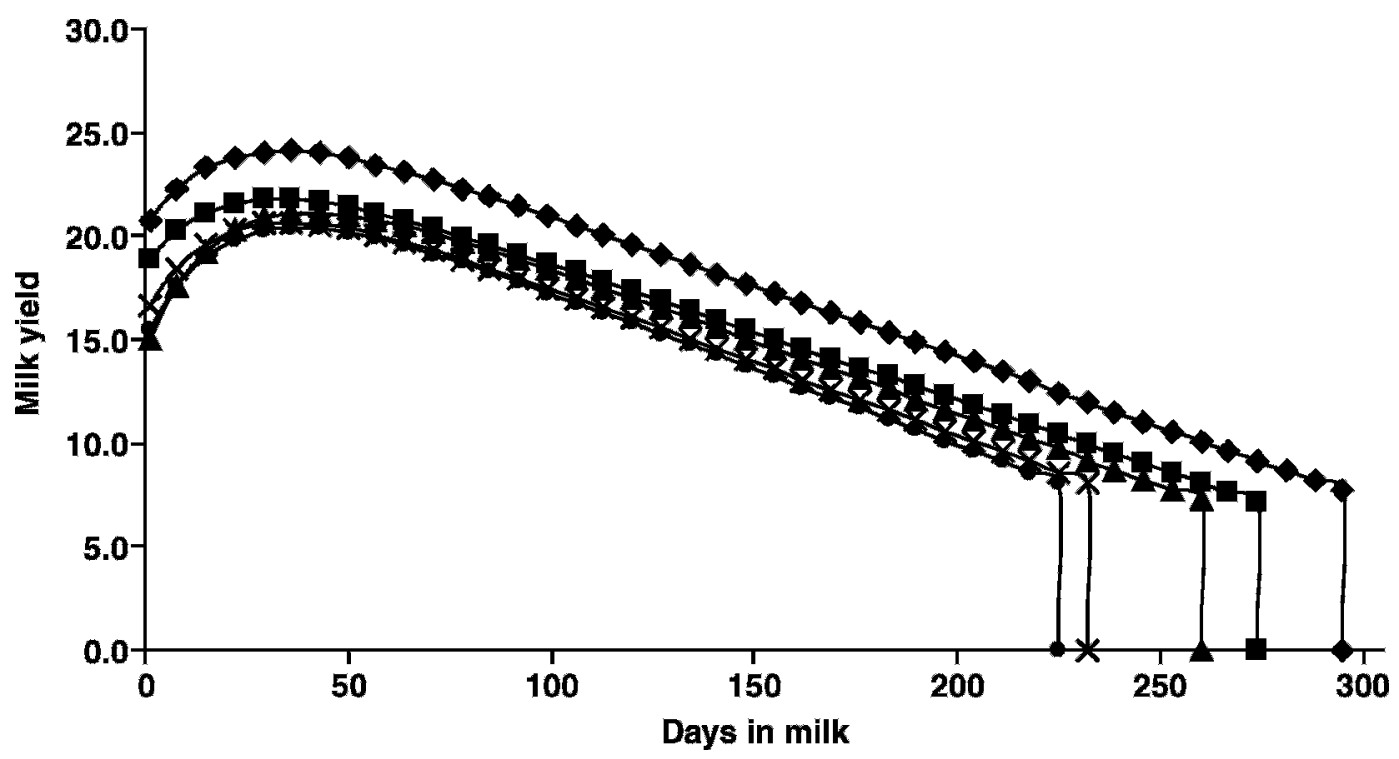

Figure 2. Effect of stocking rate on the lactation profile for milk yield (kg/cow per d). Stocking rates were $2.2(\bullet), 2.7$ ( $\mathbf{\square}), 3.1(\boldsymbol{\Delta}), 3.7$ $(\times)$, and $4.3(-)$ cows/ha. The experiment was undertaken over a 3-yr period.

resulted in differences in pasture production supports our assertion that it is a more effective and robust definition of SR at a farm-system level. Further research is required to determine the applicability of CSR across vastly different grazing systems.

The shortening of the lactation in autumn (late lactation) with increasing SR is necessary in a "closed system" in which supplementary feed is unavailable (for reasons such as availability, price, organic certification, and so on), to ensure that there is sufficient pasture grown and stored before the beginning of the new milk production season. The milk yields of cows stocked at 2.2 and 4.3 cows/ha predicted from the Wilmink function were 5,109 and 3,401 kg, respectively, and cows on these SR treatments had lactation lengths of 291 and $221 \mathrm{~d}$, respectively. If the lactation length of all herds was standardized to $305 \mathrm{~d}$ (Table 4), $24 \%$ of the reduced milk production resulting from increasing SR could be attributed to the shorter lactation lengths, whereas $76 \%$ was a result of the lower peak and less persistent lactation.

Although there was a linear decline in calving BCS with increasing SR (Table 3), a factor known to negatively affect milk production, the difference between the highest and lowest SR (0.5 BCS units; 10-point system) would only have been expected to reduce milk yield by $73 \mathrm{~kg}$ milk (Roche et al., 2007b) or $4 \%$. Therefore, the reason for the lower yield per cow as SR increased was most likely a result of the lower intakes of fresh pasture during winter (early lactation). Intakes estimated using a dual indigestible marker system $(n-$ alkanes; Dillon and Stakelum, 1989) showed a quadratic decline in pasture consumed during winter. This is consistent with the tendency for milk and FCM yield $(P<0.1)$ to decline quadratically with increasing SR, and is supported by the increasing deficit in pasture availability in early lactation with increasing SR (Figure 1). Cows on the high stocked treatments received pasture silage in lieu of available fresh pasture, but even high quality pasture silage does not support milk production as effectively as fresh pasture (Dillon et al., 2002). This is an important observation because it infers that if feed of equivalent quality to the pasture being consumed were purchased for the more highly stocked herds in early lactation to elevate their lactation profile, and in particular their peak milk yield, to that of the less severely stocked herds, it may be possible to capture more than $70 \%$ of the difference in milk production per cow between SR with only a modest investment in supplementary feeds in early lactation. This is consistent with the lack of effect of SR on milk yield per cow in the study of Fales et al. (1995) and the recent findings of Roche (2007), who reported responses to supplementing restricted cows with additional pasture during the first $5 \mathrm{wk}$ of lactation that were 2 times greater than the immediate response measured and approximately 2.5 times greater than the average published response (Bargo et al., 2003). Further research is required to determine the benefit of strategic use of supplementary feeds to dairy cows on high SR systems in early lactation.

Although there was a negative association between SR and milk yield per cow, the effect of SR on milk 
Table 5. Effect of stocking rate ${ }^{1}$ on the proportion of cows calved in the first 4, 6 , and 8 wk of the seasonal calving period and the number of days from planned start of calving (PSC) until $50 \%$ of cows were calved; the proportion of cows hormonally induced to calve ${ }^{2}$; the proportion of cows anestrus at planned start of mating; the 21-d submission rate (SR21) ${ }^{3}$; and the proportion of cows pregnant at either 28 (PR28), 42 (PR42), or 84 (PR84) d from planned start of mating

\begin{tabular}{lcccccccc}
\hline & \multicolumn{9}{c}{ Stocking rate } & & \multicolumn{2}{c}{$P$-value } \\
\cline { 2 - 4 } & 2.2 & 2.7 & 3.1 & 3.7 & 4.3 & & Linear & Quadratic \\
\hline Calved & & & & & & & \\
Wk 4 & 0.80 & 0.77 & 0.81 & 0.74 & 0.75 & 0.23 & 0.97 \\
Wk 6 & 0.93 & 0.90 & 0.96 & 0.89 & 0.84 & 0.21 & 0.34 \\
Wk 8 & 0.98 & 0.97 & 0.98 & 1.00 & 0.96 & & 0.96 & 0.58 \\
PSC to midpoint & 17.1 & 16.9 & 16.4 & 16.5 & 17.5 & & 0.76 & 0.07 \\
Induced $^{2}$ & 0.09 & 0.12 & 0.14 & 0.06 & 0.05 & & 0.26 & 0.37 \\
Anestrus $_{\text {Submission rate }}{ }^{3}$ & 0.26 & 0.40 & 0.25 & 0.33 & 0.51 & 0.21 & 0.51 \\
PR28 & 0.91 & 0.90 & 0.88 & 0.85 & 0.88 & 0.14 & 0.30 \\
PR42 & 0.48 & 0.58 & 0.58 & 0.61 & 0.65 & $<0.05$ & 0.38 \\
PR84 & 0.63 & 0.65 & 0.72 & 0.70 & 0.68 & 0.25 & 0.18 \\
\hline
\end{tabular}

${ }^{1}$ Dairy cows were stocked at $2.2,2.7,3.1,3.7$, or 4.3 cows/ha. The experiment was undertaken over a 3 yr period.

${ }^{2}$ Cows with a due calving date later than wk 8 of the seasonal calving period were hormonally induced to calve during wk 7 and 8 using a 2-step combination of dexamethasone and prostaglandin, provided they had low SCC before dry-off $(<200,000$ cells $/ \mathrm{mL}$ ), were in a BCS of 5.0 (on a 10-point scale) or greater, and blood $\mathrm{Mg}(>0.8 \mathrm{mmol} / \mathrm{L})$ and $\gamma$-glutamyl transferase (15 to $22 \mathrm{U} / \mathrm{L}$ plasma) measured the week before planned induction did not indicate health concerns.

${ }^{3}$ Proportion of cows submitted for insemination in the first 3 wk of the breeding period.

yield per hectare was positive (Table 3 ). This is consistent with earlier research findings (Castle et al., 1968, 1972; Gordon, 1973; Fales et al., 1995) in which milk production per hectare increased with increasing SR irrespective of the effect of SR on milk yield per cow. In fact, Castle et al. (1972) reported that SR explained $92 \%$ of the variation in milk production per hectare. Irrespective of SR, there was no significant $(P=0.25)$ effect on the amount of milk produced per kilogram of feed consumed $(0.9 \mathrm{~kg}$ of milk $/ \mathrm{kg}$ of pasture + silage consumed). However, the decline in protein percentage and the tendency for a decline in milk fat with increasing $\mathrm{SR}$ resulted in a decline in milk fat and protein yield, FCM, and $\mathrm{NE}_{\mathrm{L}}$ per kilogram of feed consumed $(P$ $<0.05$; adjusted $\mathrm{R}^{2}=0.79,0.74$, and 0.73 , respectively) with increasing SR, implying a reduced efficiency of converting available pasture into saleable product. This would be expected considering the linear increase in energy required per hectare for maintenance, activity, and pregnancy as SR increases. However, the effect is small, with a decline of 3 to $5 \%$ in feed DM conversion efficiency with each additional cow per hectare and is offset by the $5.5 \%$ increase in pasture DM availability and the increase in pasture ME with increasing SR.

\section{Reproduction}

Seasonal pasture-based systems require a compact calving season ( 8 to $10 \mathrm{wk}$ ) and an intercalving interval of $365 \mathrm{~d}$ to ensure that maximum animal demand coin- cides with peak pasture growth (Dillon et al., 1995). Consequently, the seasonal nature of milk production in such systems places additional requirements on reproductive performance in that cows need to initiate ovarian cyclicity early after calving and preferably conceive within 6 wk from a fixed calendar date (PSM; Roche et al., 2007a) to achieve the 365-d intercalving interval. The effect of SR on the measured reproductive variables and the pattern of calving is presented in Table 5. There was no effect of SR or CSR on the proportion of cows that calved within the first 4,6 , or $8 \mathrm{wk}$ following the onset of calving. Between 75 and $80 \%$ of cows calved in the first $4 \mathrm{wk}$ and between 95 and $100 \%$ calved within the desired 8-wk window. The number of cows induced to achieve this calving spread was not significantly affected by SR, but declined in a quadratic fashion with increasing CSR.

Similarly, none of the measured reproductive variables were significantly affected by SR, although the number of cows pregnant $4 \mathrm{wk}$ following the PSM increased with increasing SR and CSR. The number of cows pregnant 12 wk following PSM increased $(P<$ 0.05) in a quadratic fashion with increasing CSR. It is difficult to draw any firm conclusions on the effect of SR or CSR on reproduction with such a small data set. However, in general even the numerical tendencies do not tend to point toward a negative effect of SR. The only numerical tendency toward lower reproductive success is a greater proportion of cows anestrous at PSM in the cows stocked at 4.3 cows/ha compared with 
any of the rest of the herds (Table 5). This is consistent with the tendency for a linear decline in the number of cows submitted to AI in the first $3 \mathrm{wk}$ of the breeding season as SR $(P<0.15)$ and CSR $(P=0.07)$ increased. Several authors have linked low calving BCS, as was evident with increasing SR and CSR, with longer periods of postpartum anestrus (Markusfeld et al., 1997; Titterton and Weaver, 1999; Roche et al., 2007a), but calving BCS has been reported to not affect pregnancy (Buckley et al., 2003; Roche et al., 2007a). This lack of effect of SR on pregnancy rate is probably because all cows had sufficient fresh pasture to meet demand for the month before PSM. In addition, the quality of pasture on offer increased with increasing SR.

\section{CONCLUSIONS}

Stocking rate should balance the dual objectives of generous feeding to achieve high levels of efficiency of milk production per cow while maintaining high levels of pasture utilization to meet the overall objective of optimizing farm profitability. In the current study the amount of pasture grown tended to increase with increasing SR, and the quality of the pasture on offer increased linearly, reducing the potential impact of cows per hectare. Milk production per cow declined linearly with increasing SR, primarily because of a lower peak and less persistent milk profile and a shorter lactation. However, milk production per hectare increased linearly, and there was only a small decline in the efficiency of converting feed energy into milk energy as SR increased. Stocking rate did not affect reproductive success.

Comparisons with other studies support the need for a more robust measure of SR than cows per hectare, because farms will differ in the genetic merit of their cows, in their potential to produce pasture, and in their ability to import suitable feed supplements. We propose the concept of a CSR, whereby SR is defined by the BW of the cows, the potential of the land to produce pasture, and the amount of supplement sourced externally to the allocated grazing area ( $\mathrm{kg}$ of BW/t of DM). Although $\mathrm{SR}$ is sufficient to compare between very similar farming systems, the adoption of CSR would facilitate the extrapolation and transfer of research findings between different systems.

\section{ACKNOWLEDGMENTS}

The authors acknowledge the assistance of D. Berry, the technical ability of C. Leydon-Davis, J. Lile, and J. Lee, the statistical expertise of B. Dow, and all the help afforded them by No 2. Dairy staff, in particular by M. Coulter. This work was funded by New Zealand Dairy Farmers through DairyNZ, Hamilton, New Zealand.

\section{REFERENCES}

Baker, A.-M. C., and J. D. Leaver. 1986. Effect of stocking rate in early season on dairy cow performance and sward characteristics. Grass Forage Sci. 41:333-340.

Barbano, D. M., J. M. Lynch, and J. R. Fleming. 1991. Direct and indirect determination of true protein content of milk by Kjeldahl analysis: Collaborative study. J. Assoc. Off. Anal. Chem. 74:281-288.

Bargo, F., L. D. Muller, E. S. Kolver, and J. E. Delahoy. 2003. Invited review: Production and digestion of supplemented dairy cows on pasture. J. Dairy Sci. 86:1-42

Berry, D. P., F. Buckley, P. Dillon, R. D. Evans, M. Rath, and R. F. Veerkamp. 2003. Genetic relationships among body condition score, body weight, milk yield, and fertility in dairy cows. J. Dairy Sci. 86:2193-2204.

Buckley, F., K. O'Sullivan, J. F. Mee, R. D. Evans, and P. Dillon. 2003. Relationships among milk yield, body condition, cow weight, and reproduction in spring-calved Holstein-Friesians. J. Dairy Sci. 86:2308-2319.

Castle, M. E., A. D. Drysdale, and J. N. Watson. 1968. The effect of stocking rate and supplementary concentrate feeding on milk production. Grass Forage Sci. 23:137-143.

Castle, M. E., E. MacDaid, and J. N. Watson. 1972. Some factors affecting milk production from grassland at the Hannah Institute, 1951-70. J. Br. Grassl. Soc. 27:87-92.

Cliff, S. C., G. R. Morris, I. S. Hook, and K. L. Macmillan. 1995. Calving patterns in dairy heifers following single "set-time" inseminations and re-synchrony preceding second inseminations. Proc. N.Z. Soc. Anim. Prod. 55:70-71.

Corson, D. G., G. C. Waghorn, M. J. Ulyatt, and J. Lee. 1999. Forage analysis and livestock feeding. Proc. N.Z. Grassl. Assoc. 61:127-132.

Dillon, P., S. Crosse, B. O'Brien, and R. W. Mayes. 2002. The effect of forage type and level of concentrate supplementation on the performance of spring-calving dairy cows in early lactation. Grass Forage Sci. 57:212-223.

Dillon, P., S. Crosse, G. Stakelum, and F. Flynn. 1995. The effect of calving date and stocking rate on the performance of springcalving dairy cows. Grass Forage Sci. 50:286-299.

Dillon, P., J. R. Roche, L. Shalloo, and B. Horan. 2005. Optimising financial returns from grazing in temperate pastures. Pages 131147 in Utilisation of Grazed Grass in Temperate Animal Systems. Proc. Satellite Workshop, 20th Int. Grassl. Congr., Cork, Ireland.

Dillon, P., and G. Stakelum. 1989. Herbage and dosed alkanes as a grass measurement technique for dairy cows. Ir. J. Agric. Res. 28:104. (Abstr.)

Fales, S. L., L. D. Muller, S. A. Ford, M. O'Sullivan, R. J. Hoover, L. A. Holden, L. E. Lanyon, and D. R. Buckmaster. 1995. Stocking rate affects production and profitability in a rotationally grazed pasture system. J. Prod. Agric. 8:88-96.

Foot, A. S., and C. Line. 1960. Dairy production from grazed pasture: A comparison of two methods of controlled grazing at two rates of stocking. Grass Forage Sci. 15:155-162.

Gordon, F. J. 1973. The effect of high nitrogen levels and stocking rates on milk output from pasture. J. Br. Grassl. Soc. 28:193-201.

Hunt, L. A., and R. W. Brougham. 1967. Some changes in the structure of a perennial ryegrass sward frequently but leniently defoliated during the summer. N.Z. J. Agric. Res. 10:397-404.

International Dairy Federation. 1987. Milk: Determination of fat content-Röse Gottlieb gravimetric method (reference method). Standard FIL-IDF. Vol. 1C. IDF, Brussels, Belgium.

Kennedy, E., M. O’Donovan, J. P. Murphy, F. P. O'Mara, and L. Delaby. 2006. The effect of initial spring grazing date and subsequent stocking rate on the grazing management, grass dry matter intake and milk production of dairy cows in summer. Grass Forage Sci. 61:375-384.

Lee, J. M., D. J. Donaghy, and J. R. Roche. 2008. Effect of defoliation severity on regrowth and nutritive value of perennial ryegrass (Lolium perenne L.) dominant swards. Agron. J. doi:10.2134/ agronj.2007-0099 
Lee, J. M., D. J. Donaghy, and J. R. Roche. 2007. The effect of grazing severity and fertilizer application during winter on herbage regrowth and quality of perennial ryegrass (Lolium perenne L.). Aust. J. Exp. Agric. 47:825-832.

Macdonald, K. A., and J. W. Penno. 1998. Management decision rules to optimise milksolids production on dairy farms. Proc. N.Z. Soc. Anim. Prod. 58:132-135.

Maher, J., G. Stakelum, and M. Rath. 2003. Effect of daily herbage allowance on the performance of spring-calving dairy cows. Ir. J. Agric. Food Res. 42:229-241.

Markusfeld, O., N. Gallon, and E. Ezra. 1997. Body condition score, health, yield and fertility in dairy cows. Vet. Rec. 141:67-72.

McGrath, J. M., J. W. Penno, K. A. Macdonald, and W. A. Carter. 1998. Using nitrogen to increase dairy farm profitability. Proc. N.Z. Soc. Anim. Prod. 58:117-120.

McMeekan, C. P. 1956. Grazing management and animal production. Pages 146-156 in Proc. 7th Int. Grassl. Congr., Massey Agricultural College, Palmerston North, New Zealand. G. J. Neale, ed. Wright and Carman Ltd., Wellington, New Zealand.

Mrode, R. A. 1996. Linear Models for the Prediction of Animal Breeding Values. CAB International, Wallingford, UK.

O’Donovan, M., J. Connolly, P. Dillon, M. Rath, and G. Stakelum. 2002b. Visual assessment of herbage mass. Ir. J. Agric. Food. Res. 41:201-211.

O'Donovan, M., P. Dillon, M. Rath, and G. Stakelum. 2002a. A comparison of four methods of herbage mass estimation. Ir. J. Agric. Food. Res. 41:17-27.

Poppi, D. P., T. P. Hughes, and P. J. L'Huillier. 1987. Intake of pasture by grazing ruminants. Pages 55-63 in Feeding Livestock on Pasture. A. M. Nicol, ed. N.Z. Soc. Anim. Prod. Publ. No. 10. NZ Soc. Anim. Prod., Lincoln University, New Zealand.

Roche, J. R. 2007. Milk production responses to pre- and postcalving dry matter intake in grazing dairy cows. Livest. Sci. 110:12-24.
Roche, J. R., and D. P. Berry. 2006. Periparturient climatic, animal, and management factors influencing the incidence of milk fever in grazing systems. J. Dairy Sci. 89:2775-2783.

Roche, J. R., D. P. Berry, and E. S. Kolver. 2006. Holstein-Friesian strain and feed effects on milk production, bodyweight and body condition score profiles in grazing dairy cows. J. Dairy Sci. 89:3532-3543.

Roche, J. R., P. G. Dillon, C. R. Stockdale, L. H. Baumgard, and M. J. VanBaale. 2004. Relationships among international body condition scoring systems. J. Dairy Sci. 87:3076-3079.

Roche, J. R., J. M. Lee, K. A. Macdonald, and D. P. Berry. 2007b. Relationships among body condition score, body weight, and milk production variables in pasture-based dairy cows. J. Dairy Sci. 90:3802-3815.

Roche, J. R., K. A. Macdonald, C. R. Burke, J. M. Lee, and D. P. Berry. 2007a. Associations between body condition score, body weight and reproductive performance in seasonal-calving pasture-based dairy cattle. J. Dairy Sci. 90:376-391.

SAS Institute. 2006. User's Guide Version 9.1: Statistics. SAS Institute Inc., Cary, NC.

Spörndly, E. 1989. Effects of diet on milk composition and yield of dairy cows with special emphasis on milk protein content. Swed. J. Agric. Res. 19:99-106.

Titterton, M., and L. D. Weaver. 1999. The relationship between body condition at calving, uterine performance postpartum and trends in selected blood metabolites postpartum in high yielding Californian dairy cows. Pages 335-339 in Fertility in the High-Producing Dairy Cow. M.G. Diskin, ed. BSAS Occas. Publ. No. 26. Br. Soc Anim. Sci., Penicuik, UK.

Voisin, A. 1959. Grassland Productivity. Crosby-Lockwood, London, UK.

Wilmink, J. B. M. 1987. Adjustment of lactation yield for age at calving in relation to level of production. Livest. Prod. Sci. 16:321-334. 